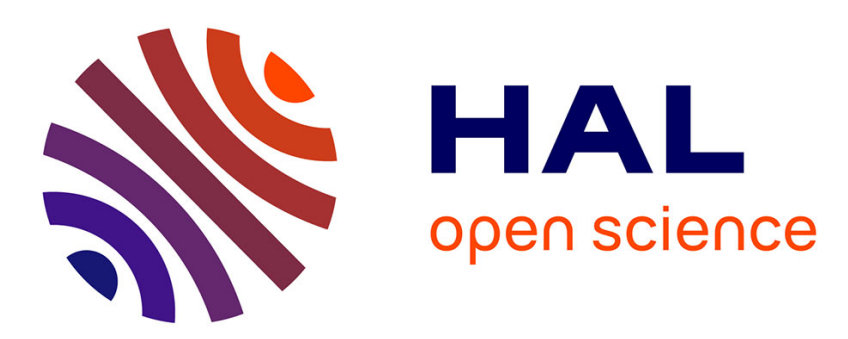

\title{
A gene coding for a monomeric form of cucumber mosaic virus satellite RNA confers tolerance to CMV
}

Mireille Jacquemond, Joëlle Amselem, Mark Tepfer

\section{To cite this version:}

Mireille Jacquemond, Joëlle Amselem, Mark Tepfer. A gene coding for a monomeric form of cucumber mosaic virus satellite RNA confers tolerance to CMV. Molecular Plant-Microbe Interactions, 1988, 8 (1), pp.311-316. 10.1094/MPMI-1-311 . hal-02726709

\section{HAL Id: hal-02726709 \\ https://hal.inrae.fr/hal-02726709}

Submitted on 2 Jun 2020

HAL is a multi-disciplinary open access archive for the deposit and dissemination of scientific research documents, whether they are published or not. The documents may come from teaching and research institutions in France or abroad, or from public or private research centers.
L'archive ouverte pluridisciplinaire HAL, est destinée au dépôt et à la diffusion de documents scientifiques de niveau recherche, publiés ou non, émanant des établissements d'enseignement et de recherche français ou étrangers, des laboratoires publics ou privés.

\section{다(1)(2)}

Distributed under a Creative Commons Attribution - ShareAlikel 4.0 International 


\title{
A Gene Coding for a Monomeric Form of Cucumber Mosaic Virus Satellite RNA Confers Tolerance to CMV
}

\author{
Mireille Jacquemond, ${ }^{1}$ Joelle Amselem, ${ }^{2}$ and Mark Tepfer ${ }^{2}$ \\ ${ }^{1}$ Station de Pathologie Végétale, INRA-Domaine Saint Maurice, B.P. 94, 84140 Montfavet, France, and ${ }^{2}$ Laboratoire de Biologie \\ Cellulaire, INRA-Centre de Versailles, 78026 Versailles cédex, France. \\ Received 14 September 1988. Accepted 3 November 1988.
}

\begin{abstract}
A gene whose transcript bears a monomeric form of cucumber mosaic virus (CMV) satellite RNA was introduced into tobacco (Nicotiana tabacum 'Xanthi' nc) plants by using an Ri plasmidbased vector system. On CMV infection, the transcript of the satellite RNA gene was used as a template to yield unit-length satellite RNA, which was efficiently amplified by the virus. Plants
\end{abstract}

bearing the satellite RNA gene displayed long-term tolerance to CMV infection and were also tolerant to CMV infection by aphids, the natural vector of CMV. Implications of these results concerning the mechanism of satellite RNA replication are discussed.

Additional keywords: transgenic plants, viral resistance.

The first experiments dealing with the introduction of foreign genes into plants used disarmed Ti plasmid vectors to transfer chimeric antibiotic resistance genes to plants (Bevan et al. 1983; Fraley et al. 1983; Herrera-Estrella et al. 1983). More recently, and particularly during the last three years, this system has been exploited for the transfer of traits of agronomic importance such as tolerance to herbicides (Comai et al. 1985; Shah et al. 1986; De Block et al. 1987), to insects (Fischoff et al. 1987; Hilder et al. 1987; Vaeck et al. 1987), to bacteria (Jaynes et al. 1987), and also to viruses. Three different types of genes have been developed to confer virus tolerance in plants: ones coding for the viral coat protein (Powell-Abel et al. 1986; Loesch-Fries et al. 1987; Tumer et al. 1987; Van Dun et al. 1987; Cuozzo et al. 1988; Hemenway et al. 1988), ones coding for antisense RNA (Cuozzo et al. 1988; Hemenway et al. 1988), or ones whose transcript corresponds to a precursor of viral satellite RNA (Gerlach et al. 1987; Harrison et al. 1987).

These approaches differ greatly, both in terms of the mechanisms of resistance or tolerance involved, as well as in terms of how resistance is expressed. Genes encoding coat protein or antisense RNA confer resistance whose effectiveness depends on the level of expression of the gene introduced and the concentration of the viral inoculum; in many cases these types of resistance are overcome by high levels of inoculum. Except for the resistance conferred by the capsid of potato virus X (Hemenway et al. 1988), resistance due to the coat protein can also be overcome by an inoculum of purified viral RNA. When genes based on satellite RNA are used, tolerance is observed whatever the strain of virus, the form (RNA or virus particles), the concentration of the inoculum, and the level of satellite RNA gene transcription. Of course, this strategy is limited to the few viruses possessing a satellite RNA that limits their replication.

Cucumber mosaic virus (CMV) infects more than 800 higher plant species (Douine et al. 1979) and causes severe losses in many crop species worldwide. For most of them, no

(๑) 1988 The American Phytopathological Society natural disease resistance is available. CMV has a divided genome composed of three RNA species plus a subgenomic RNA. Certain strains exhibit a supernumerary RNA component that has been demonstrated to be a true satellite RNA (Diaz-Ruiz and Kaper 1977; Lot et al. 1977; Gould et al. 1978). This satellite RNA is of particular interest because it greatly reduces the synthesis of the viral genome in the infected plant (Kaper and Tousignant 1977; Mossop and Francki 1979; Takanami 1981; Jacquemond and Leroux 1982). For nearly all hosts tested so far, this reduction of virus replication correlates with an important attenuation of the symptoms induced by the virus alone. Satellite RNA worsening symptoms of CMV infection on tobacco (Takanami 1981; Palukaitis 1988) and tomato has been described. The biological response of tomato makes it possible to distinguish at least two groups of satellite RNA depending on whether the plant develops attenuated symptoms, as is true for other hosts, or lethal necrosis (Jacquemond and Lot 1981; Kaper et al. 1981). Study of interference between the two kinds of satellite RNA has shown that tomato plants infected with a strain containing a nonnecrogenic satellite RNA are protected against infection with one containing a necrogenic satellite RNA (Jacquemond 1982).

All these results suggest that introducing a chimeric gene whose transcript corresponds to satellite RNA into plants could be a means for conferring tolerance to CMV. This approach has already been tested; Baulcombe and his colleagues (Harrison et al. 1987) have shown that tobacco plants expressing genes whose transcript corresponds to 1.3 or 2.3 units of satellite RNA are partially protected against infection by CMV. Protection has also been obtained with transgenic plants expressing tobacco ringspot virus satellite RNA genes corresponding to oligomeric forms of satellite RNA (Gerlach et al. 1987). Here we report that similar protection is obtained after introduction into host plants, with an Ri-plasmid-based vector, of a chimeric gene containing a monomeric copy of CMV satellite RNA. The presence of nonviral sequences, corresponding to the homopolymeric tails added for the synthesis and the cloning 
of the cDNA as well as a fragment of the cloning vector (Jacquemond and Lauquin 1988), does not interfere with the biological activity of the transcripts. Moreover, these plants are equally tolerant when infected either by mechanical inoculation or with viruliferous aphids, the natural vector of CMV.

\section{MATERIALS AND METHODS}

Plasmids and bacterial strains. Restriction endonuclease digestions, ligations, transformation of Escherichia coli, maxi- and mini-preps of plasmid DNA, and other usual molecular biology techniques were as described in Maniatis et al. (1982).

Transformation of Nicotiana tabacum. The techniques used to transfer the intermediate vector pMarsat36 to Agrobacterium rhizogenes A4, to inoculate stem segments of tobacco ( N. tabacum 'Xanthi' nc, strain XHFD8), and to regenerate transformed plants from the resultant transformed roots were as described by Tepfer and CasseDelbart (1987). Briefly, pMarsat36 was introduced into $A$. rhizogenes A4 by triparental matings by using pRK2013 as helper plasmid. The resulting $A$. rhizogenes strain bearing the cointegrate between pMarsat 36 and pRiA 4 was used to inoculate surface-sterilized tobacco stem segments in vitro. Transformed roots were decontaminated, maintained as organ clones, and induced to regenerate plantlets.

Isolation of total RNA and northern analysis. Total RNA was isolated from axenic root cultures and transformed tobacco plants before and after inoculation by using the technique of Chirgwin et al. (1979), followed by a $\mathrm{CsCl}$ gradient according to Glisin et al. (1974). Samples of RNA were analyzed by electrophoresis in formaldehyde denaturing gels as described by Lehrach et al. (1977) and transferred to Amersham Hybond-N nylon membranes, according to the manufacturer's protocol. ${ }^{32} \mathrm{P}$-labeled probes were prepared from isolated fragments of satellite RNA cDNA by using random oligonucleotide priming as described by Feinberg and Vogelstein (1983).

Infection of transgenic tobacco plants with CMV. The satellite-RNA-free strain of CMV, I17F, was maintained on tomato (cv. Monalbo) either to keep it satellite-RNA-free or to detect satellite RNA if it accumulates during virus replication. Leaves, 10-15 days postinoculation, were dried over $\mathrm{CaCl}_{2}$ and further used as inoculum after grinding in 10 $\mathrm{ml}$ of $0.03 \mathrm{M} \mathrm{Na} \mathrm{Na}_{2}$-phosphate, $0.2 \%$ DIECA (sodium diethyldithiocarbamate) per gram of fresh tissue. Young tobacco plants (five developed leaves) were mechanically inoculated (the whole plant was rubbed with inoculum) and placed in an insect-proof greenhouse compartment for at least 1 mo.

Aphid transmission was performed as described by Lecoq et al. (1979) with Myzus persicae or Aphis gossypii. The virus source was melon (Cucumis melo 'Cantaloup charentais') infected with $\mathrm{I} 17 \mathrm{~F}$ CMV strain 7 days previously. At least 10 viruliferous aphids were deposited on each tobacco plant to ensure infection. Two hr later, aphids were killed by fumigation and the plants kept in an insectfree greenhouse.

Determination of virus propagation in experimental tobacco plants. Virus was purified according to Lot $e t$ al. (1972) 7 days after inoculation. RNA was extracted from the virions by the phenol-sodium dodecyl sulfate method and analyzed on a $2.4 \%$ polyacrylamide gel. Crude extracts from a young leaf of identical position from each infected plant were prepared in phosphate buffer ( $4 \mathrm{ml} / 1 \mathrm{~g}$ of leaf). Part of the extract was assayed for biological properties on young tomato plants. Development of necrosis by these plants is characteristic of the presence of a necrogenic satellite RNA in the inoculum. The remainder of the extract was kept at $-20^{\circ} \mathrm{C}$ for quantitation of capsid protein.

The amount of capsid protein was quantified by doubleantibody sandwich ELISA (Clark and Adams 1977), with reagents prepared against the LQ strain of CMV (a gift from $\mathrm{H}$. Lot), which belongs to the same group as I17F. Crude extracts were further diluted 1,000- to 16,000-fold, depending on whether they contained satellite RNA. Controls were based on purified I $17 \mathrm{~F}$ virions diluted to $1-200 \mu \mathrm{g} / \mathrm{ml}$ in a crude extract of noninfected tobacco; control samples were further diluted, as were the experimental treatments.

\section{RESULTS}

Construction of a satellite RNA gene. A gene whose transcript corresponds to a monomeric precursor form of CMV satellite RNA was constructed by using the intermediate expression vector, pMarcel19 (Robaglia et al. 1987), which has a unique Bam HI cloning site between the cauliflower mosaic virus (CaMV) 19S promoter and a fragment bearing the polyadenylation signals of the nopaline synthase gene. The pMarcel family of vectors can be inserted by cointegration into either a wild-type $A$. rhizogenes strain A4 Ri plasmid or into certain disarmed $\mathrm{Ti}$ plasmids, such as pGV3850 (Zambryski et al. 1983).

The cDNA clone used corresponds to a single copy of a 335 -nucleotide necrogenic isolate of satellite RNA, I17N, cloned and sequenced by Jacquemond and Lauquin (1988). The BamHI fragment of this clone, with the following structure (oligo $\mathrm{dC} /$ satellite/oligo $\mathrm{dA} /$ oligo $\mathrm{dG} /$ vector fragment), was cloned in the intermediate plant expression vector pMarcel19 to create pMarsat36 (Fig. 1). We have used the Ri plasmid system described in detail elsewhere (Tepfer and Casse-Delbart 1987) to introduce pMarsat36 into tobacco plants. Transformants bearing this gene are referred to as T362(n), in which (n) is the clone number.

Expression of the satellite RNA gene in plants before and after CMV infection. Several clones of genetically transformed tobacco roots bearing the satellite RNA gene were regenerated and the resulting plantlets propagated in vitro. Southern blots of transformants confirmed the correct restriction map of the transferred genes (data not shown). Northern blots of total RNA of these plants (Fig. 2) when probed with the satellite RNA cDNA showed a single transcript of the expected size, approximately $0.95 \mathrm{~kb}$ (insert of $0.59 \mathrm{~kb}$ plus $3^{\prime}$ noncoding and poly $A$ of $0.35 \mathrm{~kb}$ ). The level of expression was quite variable among clones; for instance, clones T362(17) and T362(25) had consistently higher levels of transcript than clone T362(18). As can be seen in Figure 2, a band visible in ethidium bromide staining appeared at 0.33 $\mathrm{kb}$ in RNA extracted from T362 plants after inoculation with CMV. Densitometry of several RNA gels of different CMV-infected T362 plants showed that this band consistently represents $10-12 \%$ of the total plant RNA. Northern blots of these gels probed with the satellite RNA cDNA showed that the new band corresponds to satellite 
RNA. The satellite RNA was produced from the precursor transcript to yield unit-length monomer satellite RNA that is strongly amplified by the virus. Dimeric forms of $0.67 \mathrm{~kb}$ were also visible. The level of satellite RNA was not correlated with the level of the precursor transcript as much

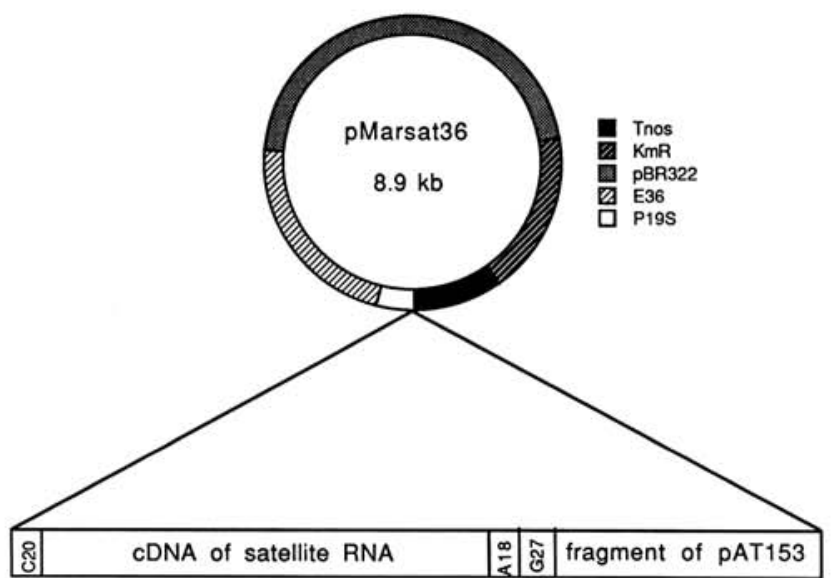

Fig. 1. Map of pMarsat36, intermediate vector bearing the satellite RNA gene. The 0.59-kb Bam HI fragment bearing a single-copy cDNA of satellite RNA isolate I17N (inset) was inserted in the unique Bam HI cloning site of the expression vector pMarcel19. The latter bears EcoRI fragment 36 of the pRiA4 TL region, as well as pBR322 sequences, allowing recombination with either $\mathrm{pRiA} 4$ or with certain disarmed Ti plasmids such as pGV3850. The oligo $(\mathrm{dA})$, oligo $(\mathrm{dC})$, and oligo $(\mathrm{dG})$ tracts and fragment of pAT153 are the result of cDNA priming and cloning in pAT153 (Jacquemond and Lauquin 1988). Tnos $=3^{\prime}$ region of nopaline synthase, $\mathrm{Km}^{\mathrm{R}}=$ kanamycinresistance gene from Tn $5, \mathrm{E} 36=E c o \mathrm{R}$ I fragment 36 of the pRiA4 Tl region, $\mathrm{P} 19 \mathrm{~S}=\mathrm{CaMV} 19 \mathrm{~S}$ promoter.

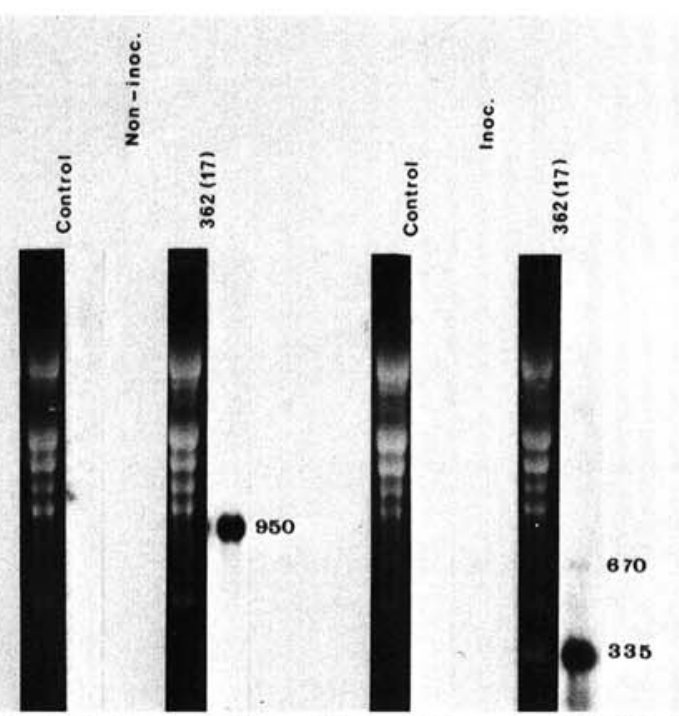

Fig. 2. Analysis of the transcript from pMarsat 36 in transgenic T362(17) plants and amplification of the resulting satellite RNA on CMV infection. Total RNAs were extracted from leaves of either noninoculated (left) or CMV-inoculated (right) plants. Control plants were transformed with the wild-type Ri plasmid. Lanes from a single ethidium bromide stained gel and the corresponding northern blot with the satellite RNA cDNA as probe are shown in pairs. Fifteen micrograms of RNA was applied per lane. The autoradiogram of RNA from noninoculated plants and control CMVinoculated plants was exposed for $48 \mathrm{hr}$ at $-80^{\circ} \mathrm{C}$ with intensifying screens, whereas the one after inoculation was exposed for $20 \mathrm{~min}$ at room temperature without screens. RNA size, indicated in nucleotides, was estimated by interpolation from the migration of standard marker RNAs (Boehringer Mannheim RNA ladder). satellite RNA was present in infected T362(18) plants as in T362(17) and T362(25) plants.

Susceptibility of transgenic plants to virus infection by mechanical inoculation. Transgenic tobacco plants regenerated from three clones of transformed roots expressing the satellite RNA gene, as well as control plants (nontransformed tobacco or tobacco bearing Ri T-DNA without a satellite RNA gene), were infected with the satellite RNA-free CMV strain I17F. Behavior of both types of control plants toward CMV (Fig. 3) was as follows: inoculated leaves and the first noninoculated leaf developed weak symptoms (vein clearing and a diffuse mosaic) during the first week after infection. Then the next two leaves exhibited severe mosaic; the leaf area was also reduced. The symptoms developed by the following two leaves were slightly milder, but those of the next ones were again very severe. Transformed plants expressing the satellite RNA gene showed weak symptoms similar to controls during the week following infection. After this, symptoms exhibited by the upper leaves were extremely attenuated; often the plants showed essentially no symptoms (Fig. 3). Similar protection was observed for the transformants of the three clones.

Virus replication, as judged by yields of viral nucleoproteins purified 7 days after infection and serological quantitation of the capsid protein, is described in Table 1. Viral replication was greatly reduced in plants expressing the satellite RNA gene, because three- to fourfold less of the virus could be recovered from these plants, and the amount of capsid was approximately $10 \%$ of that isolated from the two types of control plants. This decrease was correlated with an important accumulation of satellite RNA in the viral nucleoproteins (more than $50 \%$ of the encapsidated RNA). The same results were obtained for the three clones of transformants expressing the satellite RNA gene. No satellite RNA was detected in the preparations of virions recovered from infected control plants (results not shown). These results confirm those obtained by northern analysis of total plant RNA shown above (Fig. 2). Biological properties of this RNA were determined by inoculating young tomato plants with a crude extract from infected tobacco plants. All the plants infected with an inoculum prepared from transformants expressing

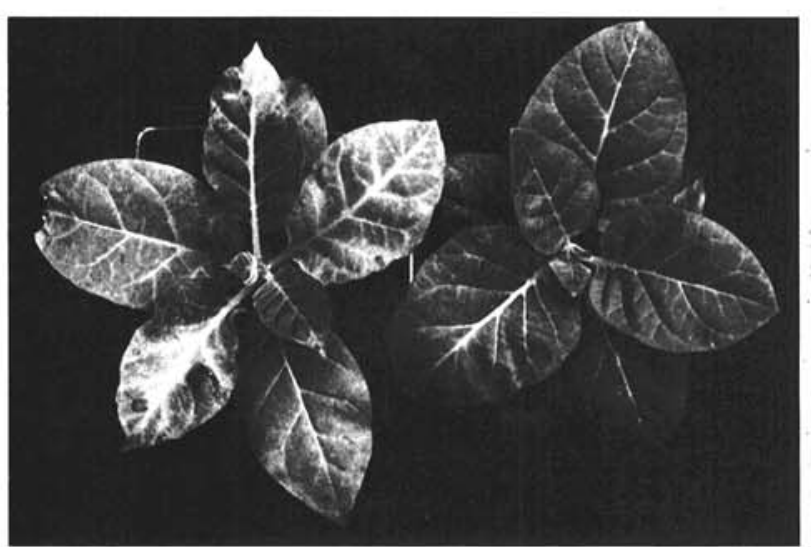

Fig. 3. Effects of expression of the satellite RNA gene on CMV symptom development 10 days after infection. Nontransformed (left) and transgenic tobacco expressing the satellite RNA gene (right) inoculated with satellite RNA-free CMV strain I17F. Note the mild leaf wrinkling due to the presence of Ri T-DNA genes (Tepfer 1984). 
the satellite RNA gene displayed lethal necrosis, whereas those infected with an inoculum prepared from control plants developed the severe fernleaf symptoms characteristic of the absence of satellite RNA in this inoculum (not shown).

Inoculation by aphids. Transformants from clones T362(17) and T362(25), as well as three types of control plants-nontransformed (Xanthi/Xanthi), transformed with the wild-type $\mathrm{Ri}$ plasmid (A4[4]/A4[4]), and transformed with the $\mathrm{Ri}$ plasmid bearing a chimeric gene unrelated to viruses (314[1]/Xanthi)-were selfed, and progeny plants from each were tested for susceptibility to infection by aphids, the natural vector for CMV. Among the progeny, transformants could be distinguished by their modified phenotype (Tepfer 1984). The modification was relatively mild (T) in transformed progeny of T362(17)/ Xanthi plants and quite pronounced $\left(\mathrm{T}^{\prime}\right)$ in transformed progeny of control A4(4)/A4(4), 314(1)/Xanthi, and of T362(25)/Xanthi ones. To see if this modification could interfere with virus transmission, control plants alone were analyzed in a first set of experiments. Results presented in Table 2, experiment 1, show that two of the three types of control plants shared similar response to CMV infection, whatever their phenotype. In subsequent experiments, control, T362(17), and T362(25) plants were tested. As shown in Table 2, experiment 2 , all of the various types of control plants exhibited severe mosaic symptoms on infection and did not produce satellite RNA as judged by the symptoms developed by the tomato plants inoculated with crude sap from these plants. On the other hand, all the plants bearing the satellite RNA gene (these plants have the modified phenotype) developed only attenuated symptoms and produced a necrogenic satellite RNA. As had been found with mechanically inoculated plants (Table 1), virus replication, as measured by capsid quantitation, was also considerably reduced in aphid-inoculated plants as compared with nontransformed sibling plants. No differences were observed in experiments with two genera of aphids, $A$. gossypii and $M$. persicae.

\section{DISCUSSION}

We have introduced a gene into tobacco whose transcript of $0.95 \mathrm{~kb}$ bears a single full-length copy of CMV satellite RNA. Northern experiments have shown that this transcript does not undergo autolytic cleavage, which has been observed for oligomeric precursors of the satellite RNA of tobacco ringspot virus (Gerlach et al. 1987). On infection with CMV however, the $0.95-\mathrm{kb}$ transcript is used as a template to yield RNA of the length of authentic satellite RNA (335 nucleotides), which is amplified to high levels (10-12\% of total RNA). Such plants display long-lasting tolerance to CMV. We observed no difference in tolerance among several clones of transformants that transcribe the satellite RNA precursor to different levels. This suggests that even lower levels of expression would be sufficient to confer CMV tolerance, and reflects the very high biological activity of satellite RNA (Jacquemond and Leroux 1982). This is in contrast to what is observed in virus-resistant plants expressing viral coat protein or antisense RNA, in which high levels of expression must be achieved to confer effective resistance.

Our observation that a precursor RNA transcript bearing

Table 1. Behavior toward CMV of plants expressing the CMV satellite RNA gene

\begin{tabular}{|c|c|c|c|c|c|c|}
\hline & \multicolumn{2}{|c|}{ Control plants } & \multirow[b]{2}{*}{ · } & \multicolumn{3}{|c|}{ Plants expressing satellite RNA gene } \\
\hline & $T^{a}$ & $\mathrm{NT}^{\mathrm{a}}$ & & T362(17) & T362(18) & T362(25) \\
\hline Number of plants & 4 & 13 & & 12 & 2 & 4 \\
\hline $\begin{array}{l}\text { Average yield of virus } \\
(\mu \mathrm{g} \text { of virus/g of leaf })^{b}\end{array}$ & $1,887(455)$ & $2,329(227)$ & & $687(148)$ & $566(27)$ & $614(99)$ \\
\hline \multicolumn{7}{|l|}{ Capsid quantitation $^{\mathrm{c}}$} \\
\hline Day 7 postinoc. & $760(165)$ & $755(171)$ & & $108(58)$ & $97(21)$ & $77(24)$ \\
\hline Day 14 postinoc. & n.a. & $775(249)$ & & $53(11)$ & $45(7)$ & $60(20)$ \\
\hline
\end{tabular}

${ }^{\mathrm{a}} \mathrm{T}=$ transformed control plants; $\mathrm{NT}=$ nontransformed control plants.

${ }^{b}$ Virus yield calculated as in Lot et al. (1972).

'Capsid concentration, measured serologically, is expressed as $\mu \mathrm{g}$ of capsid protein/g of leaf tissue; numbers in parentheses are standard deviations. Average values of all the plants expressing the satellite RNA gene are significantly different $(0.1 \%)$ from those of both types of control plants. n.a. $=$ not analyzed.

Table 2. Results of the infection by aphids of progeny from tobacco plants transformed or not with the satellite RNA gene

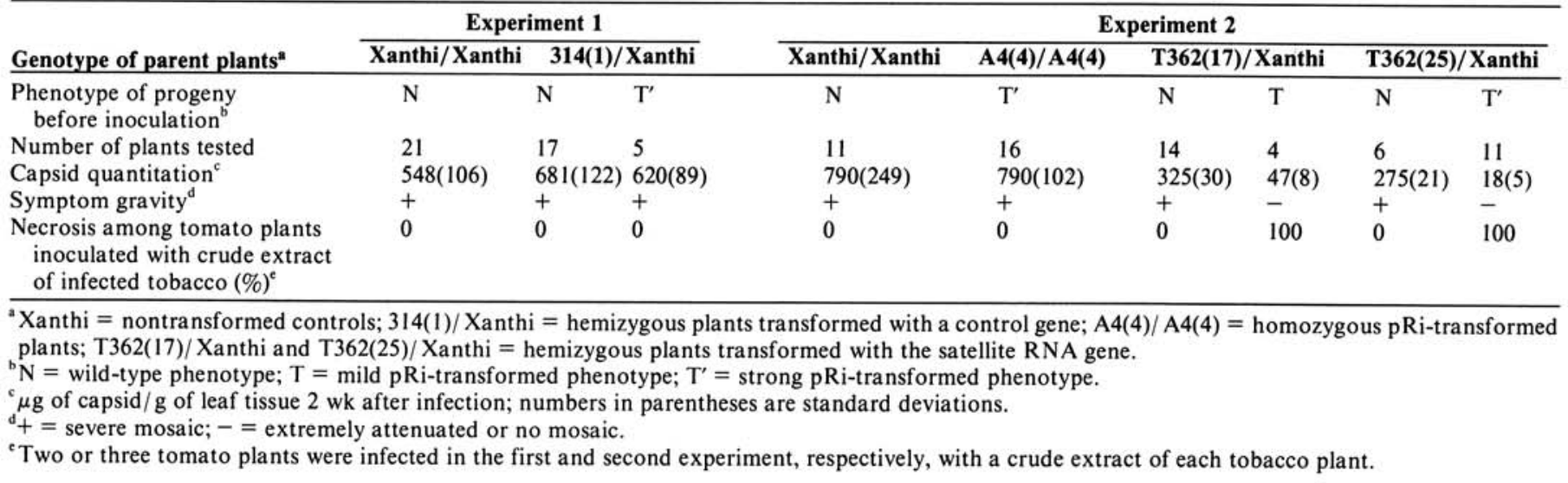


monomer-length satellite RNA, which is unlikely to circularize, is an efficient template for satellite RNA replication is consistent with the hypothesis that CMV satellite RNA is not replicated by a rolling circle-type mechanism, as appears to be the case for the satellite RNA of tobacco ringspot virus (Bruening et al. 1988). As an alternative, we would propose that the CMV replicase is capable of internal initiation on the precursor transcript, leading to production of authentic satellite RNA. In this regard, the homopolymeric tails added in cloning the satellite RNA cDNA that we have used (Jacquemond and Lauquin 1988) may be important in conferring biological activity. Collmer and Kaper (1985) have shown that the double-stranded replicative forms of CMV RNA, including the satellite RNA, have an unpaired G residue at the $3^{\prime}$ end of the $(-)$ strand (Fig. 4A). They propose that $(+)$ strand synthesis is initiated on the adjacent penultimate $\mathrm{C}$ residue of the $(-)$ strand. The oligo $(\mathrm{dC})$ tail added to the $5^{\prime}$ end of the $(+)$ strand of the satellite RNA cDNA would lead, upon replication, to synthesis of an oligo $(\mathrm{dG})$ tract adjacent to the ultimate $3^{\prime} \mathrm{C}$ of the corresponding (-) strand (Fig. 4B). A similar GC pair on the (-) strand of RNA-3 of both CMV (Collmer and Kaper 1985) and BMV (Miller et al. 1985) has
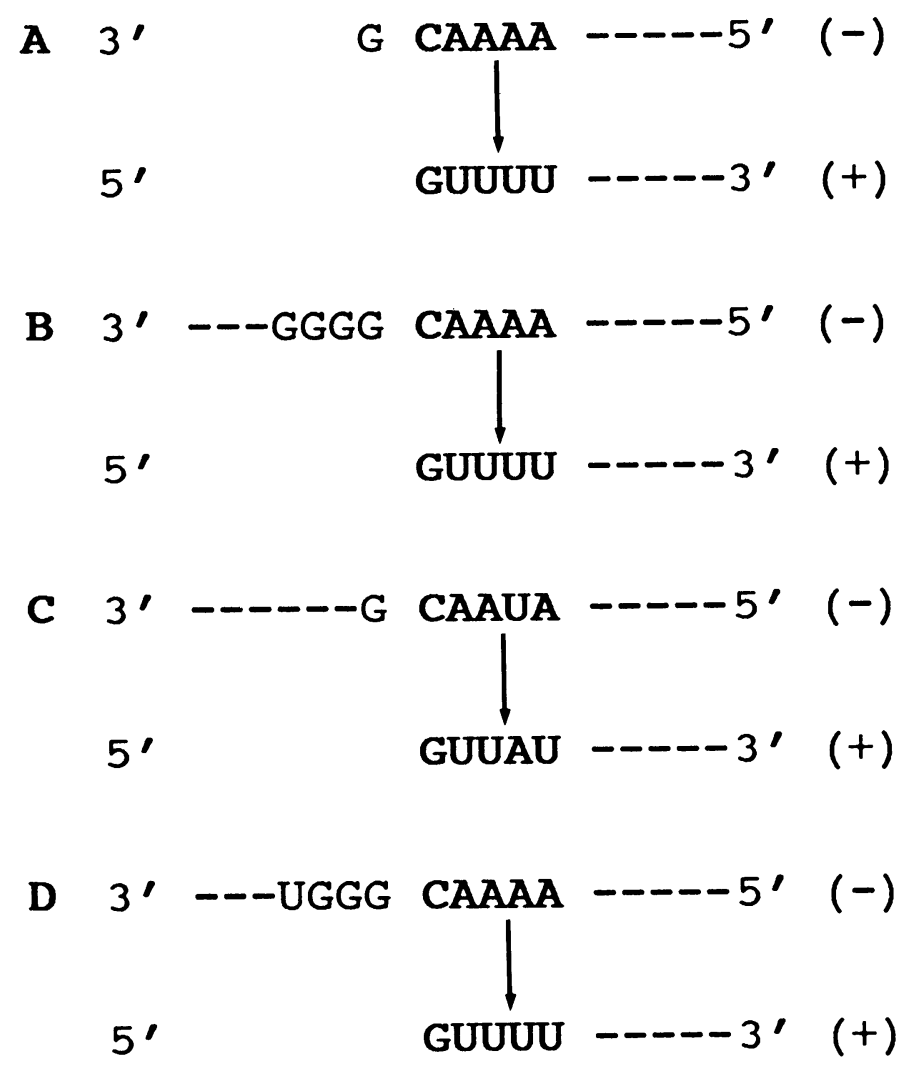

Fig. 4. Comparison of presumptive sites of initiation of synthesis of $(+)$ strand RNA on $(-)$ strand CMV satellite and genomic RNAs. A, In replicative forms of CMV satellite RNA, the $3^{\prime}$ end of the (-) strand has an unpaired $\mathrm{G}$; the corresponding $(+)$ strand is thought to initiate at the adjacent C (Collmer and Kaper 1985). B, The oligo(dG) tract $3^{\prime}$ to the $(-)$ satellite RNA precursor transcript recreates a GC pair at the site of presumed internal initiation of $(+)$ strand satellite RNA. C, The site of presumed internal initiation for synthesis of the subgenomic $(+)$ strand is at a GC pair on the (-) strand of RNA-3 (Collmer and Kaper 1985). D, The oligomeric satellite RNA precursor transcripts in the transformed plants of Baulcombe et al. (1986) also recreate a GC pair at the site of $(+)$ strand initiation. been shown to exist at the site of initiation of subgenomic (+) strand synthesis (Fig. 4C). The genes bearing oligomeric satellite RNA cDNA introduced into plants by Baulcombe et al. (1986) also recreate a GC pair in this position (Fig. 4D). It is worth noting that the 3 -terminal A of the $(+)$ strand of BMV RNA is unpaired (Miller et al. 1986), as is the case for $\mathrm{Q} \beta$ RNA (Bausch et al. 1983). This raises the possibility that the polyA tract adjacent to the satellite RNA sequence of the Marsat36 transcript may also be favorable to efficient initiation of $(-)$ strand synthesis by the CMV replicase. Experiments are currently under way to evaluate the biological importance of the homopolymeric tracts flanking the satellite RNA cDNA clone used. If the satellite RNA is produced by internal initiation and replicated without circular intermediates, how does one explain the higher order oligomeric forms observed in infected transgenic plants (Fig. 2)? It is possible that they represent ligated forms derived from the monomer, but they could also be due to a low level of fold-back replication of the monomer forms.

We have shown that plants expressing the satellite RNA gene are tolerant not only to mechanical inoculation, but also to infection by aphids, the natural vector of CMV. This is the first time that the resistance or tolerance of transgenic plants has been tested by using the natural viral vector. Considering that the widely used CaMV promoters are strongly expressed in cells associated with vascular bundles and weakly expressed in leaf epidermal or mesophyl cells (Jefferson et al. 1987), it would be extremely interesting to know if plants expressing types of resistance genes that can be overcome by high levels of inoculum, such as viral coat protein genes, are also protected against infection by insect vectors. If viruliferous aphids initially inoculate cells expressing such resistance genes at low levels, the virus might be able to replicate locally to high enough levels to overcome the resistance.

The results reported here were obtained with a necrogenic satellite RNA; it will be vital for future studies to determine the molecular basis of the necrogenic character. A particularly useful starting point could be the nonnecrogenic $\mathrm{R}$ isolate described by Jacquemond and Lauquin (1988), which differs from necrogenic isolates by only two nucleotide substitutions and one nucleotide deletion. If satellite RNA genes have potential in agriculture, it will be essential to derive nonnecrogenic satellite RNAs that are sufficiently different from necrogenic ones to avoid the possibility of creating necrogenic molecules by mutation or mistranscription in vivo.

\section{ACKNOWLEDGMENTS}

We thank $\mathrm{H}$. Lot for providing ELISA reagents and for helpful and stimulating discussions.

This research was supported by grants from the CNRS (903022), MRT (86 0827), MIR (84 V0802), and INRA (AIP 4560).

\section{LITERATURE CITED}

Baulcombe, D. C., Saunders, G. R., Bevan, M. W., Mayo, M. A., and Harrison, B. D. 1986. Expression of biologically active satellite RNA from the nuclear genome of transformed plants. Nature 321:446-449.

Bausch, J. N., Kramer, F. R., Miele, E. A., Dobkin, C., and Mills, D. R. 1983. Terminal adenylation in the synthesis of $\mathrm{RNA}$ by $\mathrm{Q} \beta$ replicase. J. Biol. Chem. 258:1978-1984.

Bevan, M. W., Flavell, R. B., and Chilton, M. D. 1983. A chimaeric antibiotic resistance gene as a selectable marker for plant cell transformation. Nature 304:184-187. 
Bruening, G., Buzayan, J., Gerlach, W., and Hampel, A. 1988. Nonenzymatic cleavage and ligation of a plant satellite RNA. Pages 495-502 in: Plant Molecular Biology. D. Von Wettstein and N. H. Chua, eds. NATO ASI Series A: Life Sciences, Vol. 140.

Chirgwin, J. M., Przybyla, A. E., Macdonald, R. J., and Rutter, W. J. 1979. Isolation of biologically active ribonucleic acid from sources enriched in ribonucleases. Biochemistry 18:5294-5299.

Clark, M. F., and Adams, A. N. 1977. Characteristics of the microplate method of enzyme-linked immunosorbent assay for the detection of plant viruses. J. Gen. Virol. 34:475-483.

Collmer, C. W., and Kaper, J. M. 1985. Double-stranded RNAs of cucumber mosaic virus and its satellite contain an unpaired terminal guanosine: Implications for replication. Virology 145:249-259.

Comai, L., Faciotti, D., Thompson, G., Rose, R. E., and Stalker, D. M. 1985. Expression in plants of a mutant aro $A$ gene from Salmonella typhinurium confers tolerance to glyphosate. Nature 317:741-744.

Cuozzo, M., O'Connell, K. M., Kaniewski, W., Fang, R. X., Chua, N. H., and Tumer, N. E. 1988. Viral protection in transgenic tobacco plants expressing the cucumber mosaic virus coat protein or its antisense RNA BioTechnology 6:549-557.

De Block, M., Botterman, J., Vandewiele, M., Dockx, J., Thoen, C., Gossele, V., Rao Movva, N., Thompson, C., Van Montagu, M., and Leemans, J. 1987. EMBO J. 6:2513-2518.

Diaz-Ruiz, J. R., and Kaper, J. M. 1977. Cucumber mosaic virusassociated RNA-5. III. Little nucleotide sequence homology between CARNA-5 and helper RNA. Virology 80:204-213.

Douine, L., Quiot, J. B., Marchoux, G., and Archange P. 1979. Recensement des espèces végétales sensibles au CMV. Etude bibliographique. Ann. Phytopathol. 11:439-475.

Feinberg, A. P., and Vogelstein, B. 1983. A technique for radiolabeling DNA restriction fragments to high specific activity. Anal. Biochem. 132:6-13.

Fischoff, D. A., Bowdish, K. S., Perlach, F. J., Marrone, P. G., McCormick, S. M., Niedermeyer, J. G., Dean, D. A., Kuzano-Kretzmer, K., Mayer, E. J., Rochester, D. E., Rogers, S. G., and Fraley, R. T. 1987. Insect tolerant transgenic tomato plants. BioTechnology 5:807-813.

Fraley, R., Rogers, S., Horsch, R., Sanders, R., Flick, J., Adams, S., Bittner, M., Brand, L., Finck, C., Fry, J., Galluppi, G., Goldberg, S., Hoffmann, N., and Woo, S. 1983. Expression of bacterial genes in plant cells. Proc. Natl. Acad. Sci. USA. 80:4803-4807.

Gerlach, W. L., Llewellyn, D., and Haseloff, J. 1987. Construction of a plant disease resistance gene, from the satellite RNA of tobacco ringspot virus. Nature 328:802-805.

Glisin, V., Crkvenjakov, R., and Byus, C. 1974. Ribonucleic acid isolated by cesium chloride centrifugation. Biochemistry 13:2633-2637.

Gould, A. R., Palukaitis, P., Symons, R. H., and Mossop, D. W. 1978. Characterization of a satellite RNA associated with cucumber mosaic virus. Virology 84:443-445.

Harrison, B. D., Mayo, M. A., and Baulcombe, D. C. 1987. Virus resistance in transgenic plants that express cucumber mosaic virus satellite RNA. Nature 328:799-802.

Hemenway, C., Fang, R. X., Kaniewski, W. K., Chua, N. H., and Tumer, N. E. 1988. Analysis of the mechanism of protection in transgenic plants expressing the potato virus $X$ coat protein or its antisense RNA. EMBO J. 7:1273-1280

Herrera-Estrella, L., Depicker, A., Van Montagu, M., and Schell, J. 1983. Expression of chimaeric genes transferred into plant cells using a Tiplasmid-derived vector. Nature 303:209-213.

Hilder, V. A., Gatehouse, A. M. R., Sheerman, S. E., Barker, R. F., and Boulter, D. 1987. A novel mechanism of insect resistance engineered into tobacco. Nature 300:160-163.

Jacquemond, M. 1982. Phénomènes d'interférence entre les deux types d'ARN satellite du virus de la mosaïque du concombre. Protection des tomates vis à vis de la nécrose létale. C. R. Acad. Sci. Paris, III 294:991-994

Jacquemond, M., and Lot, H. 1981. L'ARN satellite du virus de la mosaïque du concombre. I. Comparaison de l'aptitude à induire la nécrose de la tomate d'ARN satellites isolés de plusieurs souches du virus. Agronomie 1:927-932.

Jacquemond, M., and Leroux, J. P. 1982. L'ARN satellite du virus de la mosaïque du concombre. II. Etude de la relation virus-ARN satellite chez divers hôtes. Agronomie 2:55-62.

Jacquemond, M., and Lauquin, G. J. M. 1988. The cDNA of cucumber mosaic virus-associated satellite RNA has in vivo biological properties. Biochem. Biophys. Res. Comm. 151:388-395.

Jaynes, J. M., Xanthopoulos, K. G., Destefano-Beltran, L., and Dodds, J. H. 1987. Increasing bacterial disease resistance in plants utilizing antibacterial genes from insects. BioEssays 6:263-270.

Jefferson, R. A., Kavanagh, T. A., and Bevan, M. W. 1987. GUS-fusions: Beta-glucuronidase as a sensitive and versatile gene fusion marker in higher plants. EMBO J. 6:3907-3909.

Kaper, J. M., and Tousignant, M. E. 1977. Cucumber mosaic virusassociated RNA-5. I. Role of host plants and helper strains in determining amount associated with virions. Virology 80:186-195.

Kaper, J. M., Tousignant, M. E., and Thompson, S. M. 1981. Cucumber mosaic virus-associated RNA-5. VIII. Identification and partial characterization of a CARNA-5 incapable of inducing tomato necrosis. Virology 114:526-533.

Lecoq, H., Cohen, S., Pitrat, M., and Labonne, G. 1979. Resistance to cucumber mosaic virus transmission by aphids in Cucumis melo. Phytopathology 69:1223-1225.

Lehrach, H., Diamond-Wozney, J. M., and Boedtker, H. 1977. RNA molecular weight determinations by gel electrophoresis under denaturing conditions, a critical reexamination. Biochemistry 16:4743-4751.

Loesch-Fries, L. S., Merlo, D., Zinnen, T., Burhop, L., Hill, K., Krahn, K., Jarvis, N., Nelson, S., and Halk, E. 1987. Expression of alfalfa mosaic virus RNA-4 in transgenic plants confers virus resistance. EMBO J. 6:1845-1851

Lot, H., Marrou, J., Quiot, J. B., and Esvan, C. 1972. Contribution à l'étude du virus de la mosaïque du concombre. I. Méthode de purification rapide du virus. Ann. Phytopathol. 4:25-38.

Lot, H., Richards, K., and Jonard, G. 1977. Cucumber mosaic virus RNA-5. Partial characterization and evidence for no large sequence homologies with genomic RNAs. FEBS Lett. 80:395-399.

Maniatis, T., Fritsch, E. F., and Sambrook, J. 1982. Molecular Cloning: A Laboratory Manual. Cold Spring Harbor Laboratory, Cold Spring Harbor, NY.

Miller, W. A., Dreher, T. W., and Hall, T. C. 1985. Synthesis of brome mosaic virus subgenomic RNA in vitro by internal initiation on (-) sense genomic RNA. Nature 313:68-70.

Miller, W. A., Bujarski, J. J., Dreher, T. W., and Hall, T. C. 1986. Minus-strand initiation by brome mosaic virus replicase within the $3^{\prime}$ tRNA-like structure of native and modified RNA templates. J. Mol. Biol. 187:537-546.

Mossop, D. W., and Francki, R. I. B. 1979. Comparative studies on two satellite RNAs of cucumber mosaic virus. Virology 95:395-404.

Palukaitis, P. 1988. Pathogenecity regulation by satellite RNAs of cucumber mosaic virus: Minor nucleotide sequence changes alter host response. Mol. Plant-Microbe Interact. 1:175-181.

Powell-Abel, P., Nelson, R. S., De, B., Hoffmann, N., Rogers, S. G., Fraley, R. T., and Beachy, R. N. 1986. Delay of disease development in transgenic plants that express the tobacco mosaic virus coat protein gene. Science 232:738-743.

Robaglia, C., Vilaine, F., Pautot, V., Raymond, F., Amselem, J., Jouanin, L., Casse-Delbart, F., and Tepfer, M. 1987. Expression vectors based on the Agrobacterium rhizogenes Ri plasmid transformation system. Biochimie 69:231-237.

Shah, D. M., Horsch, R. B., Klee, H. J., Kishore, G. M., Winter, J.A ., Tumer, N. E., Hironaka, C. M., Sanders, P. R., Gasser, C. S., Aykent, S., Siegel, N. R., Rogers, S. G., and Fraley, R. T. 1986. Engineering herbicide tolerance in transgenic plants. Science 233:478-481.

Takanami, Y. 1981. A striking change in symptoms on cucumber mosaic virus-infected tobacco plants induced by a satellite RNA. Virology 109:120-126.

Tepfer, D. 1984. Transformation of several species of higher plants by Agrobacterium rhizogenes: Sexual transmission of the transformed genotype and phenotype. Cell 37:959-967.

Tepfer, M., and Casse-Delbart, F. 1987. Agrobacterium rhizogenes as a vector for transforming higher plants. Microbiol. Sci. 4:24-28.

Tumer, N. E., O’Connell, K. M., Nelson, R. S., Sanders, P. R., Beachy, R. N., Fraley, R. T., and Shah, D. M. 1987. Expression of alfalfa mosaic virus coat protein gene confers cross-protection in transgenic tobacco and tomato plants. EMBO J. 6:1181-1188.

Vaeck, M., Reynaerts, A., Hofte, H., Jansens, S., De Beuckeleer, M., Dean, C., Zabeau, M., Van Montagu, M., and Leemans, J. 1987. Transgenic plants protected from insect attack. Nature 328:33-37.

Van Dun, C. M. P., Bol, J. F., and Van Vloten-Doting, L. 1987. Expression of alfalfa mosaic virus and tobacco rattle coat protein genes in transgenic tobacco plants. Virology 159:299-305.

Zambryski, P., Joos, H., Genetello, C., Leemans, J., Van Montagu, M., and Schell, J. 1983. Ti plasmid vector for the introduction of DNA into plant cells without alteration of their normal regeneration capacity. EMBO J. 2:2143-2150 